Parte I - O Direito comparado e seus Protagonistas: QuAL uso, PARA QUAL FIM, COM QUAIS MÉTODOS? .....................................................................1

EDITORIAL ............................................................................................................... 3

"Tudo o que precisamos fazer é ter certeza de que continuaremos conversando".............................. 3

Gustavo Cerqueira e Patrícia Perrone Campos Mello

Direito comparado E METOdologia $\quad$................................................... 6

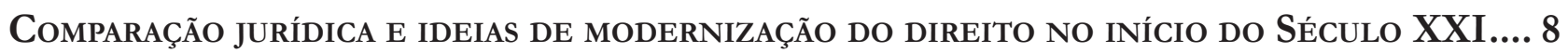
Gustavo Cerqueira

O DIREITO COMPARADO: ESFORÇO DE RESGATE HISTORIOGRÁFICO E DE PROBLEMAS METODOLÓGI$\cos$

Arnaldo Sampaio de Moraes Godoy e Gustavo Fereira Ribeiro

Direito Comparado e Política: Reflexões Necessárias .42

Raphael Carvalho de Vasconcelos e Deo Campos Dutra

Direito comparado no Brasil

L'originalité du Droit Brésilien et le Droit Comparé .57

Arnoldo Wald

LEI DA BOA RAZÃo E COMPARATISMO JURÍDICO NA DOUTRINA CIVILISTA BRASILEIRA DE 1850 A 1880

Alan Wruck Garcia Rangel

O STF EM REDE? QUANTO, COMO, COM QUE ENGAJAMENTO ARGUMENTATIVO O STF USA PRECEDENTES ESTRANGEIROS EM SUAS DECISÕES?

Patrícia Perrone Campos Mello e Felipe Meneses Graça 
Suprema Imprecisão: a metodologia em Direito Constitucional Comparado E as deficiênCias Em Seu uso pelo Supremo Tribunal Federal

Alonso Freire e Hugo Sauaia

Direitos comparados

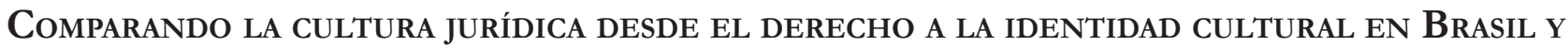

CHILE 145 Juan Jorge Faundes e Fabian Le Bonniec

O Divino e o Racional no Direito: notas para um diálogo entre sistemas jurídicos 181 Salem Hikmat Nasser e José Garcez Ghirardi

Regulação do discurso de Ódio: análise comparada em países do Sul Global 196 Jane Reis Gonçalves Pereira, Renan Medeiros de Oliveira e Carolina Saud Coutinho

Parte II - Outros temas

LA OTRA CARA DE LA MONEDA: PROTECCIÓN CONSTITUCIONAL DE LA EMPRESA, EL EMPRENDIMIENTO Y LA LIBRE COMPETENCIA EN CHILE y COLOMBiA

Juan Pablo Díaz Fuenzalida e Juan Sebastián Villamil Rodríguez

The European Court of Human Rights Decision on there 'Burqa Ban'and the CritiCal analysis of the Pragmatic experimental logic 258 Flavianne Fernanda Bitencourt Nóbrega e George Browne Rego

Direitos humanos das deslocadas ambientais e os impactos da Usina de Belo Monte: da EXPLORAÇÃO AMAZÔNICA À SUBJUGAÇÃO FEMININA

Thais Silveira Pertille e Letícia Albuquerque

Solução de Controvérsias em Acordos de Investimento: as experiênCias do CPTPP, CETA E DOS ACFIs

Fábio Morosini, Vivian Daniele Rocha Gabriel e Anastacia Costa

50 anos dos “direitos da Criança” na Convenção Americana de Direitos Humanos: a HISTÓRIA DO ARTIGO 19 311

Sven Peterke e Paloma Leite Diniz Farias 
EMPRESAS E DIREITOS HUMANOS: COMPARTILHANDO VALOR E RESPONSABILIDADES .325 Melina Girardi Fachin

CONTEMPORARY RESPONSES TO BUSINESSES' NEGATIVE HUMAN RIGHTS IMPACT 341 Andres Felipe Lopez

Human Right to LABOR PROTECTION IN UKRAINE: CURRENT SITUATION AND THE PROSPECTS OF IMPLEMENTATION OF INTERNATIONAL RULES 363 Nina Daraganova

International Regulation and Global Governance: The EU influential Method IN TIMES OF NORMATIVITY CHANGE 373 Gabriela Hühne Porto, Paula Wojcikiewicz Almeida e Juliana Maia F. A. Netto

Tecnologias digitais e o comércio de bens E SERviços na OMC/Digital. 391 Umberto Celli Junior

Los fuertes hacen lo QUe PUeden: exponiendo los límites de la Corte Penal InternaCIONAL .406

Cristián D. González-Ruiz e Víctor M. Mijares

Human Rights, Humanitarian Law and State Power 418 Renata Nagamine e João Roriz

Regional integration in the South Pacific: Challenges for Public governance .433 Joanna Siekiera

Parte III - Resenhas 443

RESENHA DA OBRA

“Democracia e policentrismo do poder", de Murilo Gaspardo 445 Angela Limongi Alvarenga Alves 


\title{
Comparação jurídica e ideias de modernização do direito no início do Século $\mathbf{X X I}{ }^{*}$
}

\author{
Comparative Law and early 21st Century \\ Ideas of Modernisation of Legal Orders
}

Gustavo Cerqueira**

\section{Resumo}

Duas ideias parecem animar a modernização do direito no início deste Século XXI: adaptação do direito às sensibilidades do tempo e adaptação do direito à concorrência internacional entre diferentes ordens e sistemas jurídicos, concorrência motivada exclusivamente por exigências econômicas. Quando mobilizado para modernizar o direito, o direito comparado poderá se ver a serviço de uma ou de outra dessas duas ideias. Em face dos desafios postos pelas ideias atuais de modernização do direito, a comparação pode revelar-se uma excelente ocasião de reflexão sobre a pertinência das soluções estrangeiras e de sua eventual transposição alhures. Nessa perspectiva, a comparação jurídica apresenta-se de forma ambivalente: ela justifica e, ao mesmo tempo, interpela a modernização projetada. Se, todavia, o direito comparado intervém, tradicionalmente, no discurso político como argumento de potencial impacto para justificar a modernização do direito — quer pelo legislador, quer pelo litigante, quer pelo juiz, quer pela doutrina -, raramente interfere como contra-argumento no momento de sopesar a pertinência e a oportunidade da modernização à luz do direito d'alhures. Por essa razão, como um dos suportes das atuais ideias de modernização do direito, a comparação jurídica pode emergir como um ato de prudência diante das ideias propulsoras da modernização almejada.

Palavras-chave: comparação jurídica - modernização do direito - individualismo - concorrência normativa - atratividade jurídica - prudência progressismo (ideologia) - conservadorismo (método).

\section{Abstract}

Two ideas seem to encourage the modernisation of law in the beginning of 21 st century: adapting the law to the sensitivities of the current times and adapting the law to the international competition amongst different legal orders and systems, competition motivated exclusively by economic requirements. When mobilized to modernise law, comparative law may be at the service of one or other of these two ideas. In view of the challenges posed by the current ideas of modernising the law, such comparison can reveal itself as an excellent opportunity to reflect on the relevance of foreign solutions and their possible transposition elsewhere. From this perspective, 
legal comparison presents itself in an ambivalent way: it justifies and at the same time challenges the projected modernization. If, however, comparative law traditionally intervenes in political discourse as an argument of potential impact in order to justify the modernization of law - whether by the legislator, the litigant, the judge or the scholars - it rarely interferes as a counterargument at the moment of weighing up the relevance and opportunity of modernization in view of the law elsewhere. That is why, as one of the basis of the current ideas of modernizing the law, legal comparison may emerge as an act of prudence in the face of the ideas that drive the desired modernization.

Keywords: legal comparison - modernisation of legal orders - individualism - regulatory competition - legal attractiveness - prudence - progressivism (ideology) conservatism (method).

\section{Introdução}

O recurso à comparação jurídica para enriquecimento do processo de modernização do direito não tende a ser relegado no Século XXI ${ }^{1}$. Pelo contrário, será cada vez mais presente nesse processo, que convém definir. Segundo o dicionário da Academia francesa, modernizar consiste em organizar, de forma moderna, adaptar-se aos gostos ou necessidades modernas. Nessa última perspectiva, modernizar o direito implicaria adaptá-lo aos gostos ou às necessidades de nosso tempo.

\footnotetext{
A orientação da comparação jurídica ad legem ferenda é muito antiga. De Licurgo e Sólon à Montesquieu, passando por Platão e Aristóteles e mesmo pelos decemviri romanos, o direito comparado sempre serviu a considerações de política legislativa. Mais perto de nós, os Séculos XIX e XX consolidaram um amplo movimento, iniciado por Montesquieu, de racionalização do estudo das legislações estrangeiras para melhor formular a lei, tomada como "la raison humaine en tant qu'elle gouverne tous les peuples de la terre" (De l'esprit des lois, t. 1, présentation par V. Goldschmidt, Paris: GF Flamarion, 1979, p. 128). Com esse objetivo foi fundada em 1869 a Société de législation comparée, cujos Estatutos determinam "l'étude et la comparaison des lois et du droit des différents pays ainsi que la recherche des moyens pratiques d'améliorer les diverses branches de la législation" (art. $1^{\circ}$, al. 1). Sobre a relação entre o direito comparado e a política legislativa, v. M. Ancel, "Politique législative et Droit comparé", Mélanges Maury, t. II, Paris: Dalloz-Sirey, 1960, p. 9-23. Sobre a atualidade do direito comparado, v. I. Aguilar Vieira, "A atualidade do direito comparado ou o direito comparado no fio do tempo", in I. Aguilar Vieira (org.), Estudos de direito comparado e de direito internacional privado (tomos I e II), pref. A. Wald, Curitiba: Juruá, 2011, p. 279-320.
}

Aos gostos..., às necessidades... a modernização do direito poderia assim responder a diferentes exigências: adaptar-se aos gostos para satisfazer sensibilidades e não a justa razão, apreciada coletivamente; adaptar-se às necessidades, o que implica submeter-se àquilo que é absolutamente obrigatório, indispensável, imprescindível, que é assim conforme a justa razão.

Essas duas ideias parecem animar a modernização do direito no início deste Século XXI. Quando mobilizado para modernização do direito, o direito comparado poderá se ver a serviço de uma ou de outra dessas duas ideias.

Isso não quer dizer que, nos séculos precedentes, essas duas ideias não estivessem presentes e entremeadas nas reformas modernizadoras do direito. Todavia, a modernização do direito no início do Século XXI parece apresentar contornos diferentes.

Quanto à primeira ideia — adaptação do direito aos gostos - ela se autonomiza da necessidade na acepção que viemos de expor para tornar-se um fundamento senão exclusivo, ao menos central das reformas. Com efeito, caracterizado por uma sociedade de "direitos $\ddot{a}$ " — direitos dos quais indivíduos pretendem ser titulares com fundamento em direitos e liberdades fundamentais e cuja garantia e respeito buscam juntamente ao poder público —, o início do Século XXI revela a existência de países, notadamente ocidentais, onde a sensibilidade de cada indivíduo, de cada grupo, de cada identidade alcança alto valor jurídico apto a fundar regras jurídicas. É o postulado individualista, que consiste em afirmar que "cada um tem o direito que sua dor seja ouvida, porque as evoluções sociais procedem de necessidades individuais". . Os debates em torno de questões de sociedade, como o direito ao aborto, à eutanásia, à procriação medicamente assistida, ou ao casamento entre pessoas do mesmo sexo, cristalizam o fenômeno, tornando muitas vezes quase irrelevante o debate sobre a (in)dispensabilidade da modernização reclamada, bem como sobre seus termos. Em muitos casos, o individualismo tomará feições de necessidade.

Quanto a essa segunda ideia, justamente, os fortes ventos reformistas que tocam hoje diversos países têm na necessidade - seja ela política, econômica e/ou social — uma razão para justificá-los. Aqui também, o fe-

\footnotetext{
2 R. Libchaber, "L'ouverture de l'assistance médicale à la procréation à toutes les femmes”, Recueil Dalloz 2018, n. 34, p. 1875-1883, p. 1879.
} 
nômeno não é novo. Ao contrário, como demonstra o advento há 250 anos da lei portuguesa da Boa Razão de 19 de Agosto de $1769^{3}$, no âmbito da ampla reforma liberal pombalina durante o reinado de Dom José I. O início do Século XXI distingue-se, todavia, dos precedentes em relação aos objetivos da modernização: hoje, a modernização responde a uma necessidade nova, a atratividade econômica dos sistemas jurídicos. Com efeito, nosso tempo é marcado por uma forte concorrência internacional entre diferentes ordens e sistemas jurídicos, motivada, essencialmente, por exigências de eficiência econômica do direito. Essa concorrência é possível em razão da extensão mundial da autonomia da vontade, cujo corolário maior é liberdade de escolha da lei aplicável às relações privadas, ingrediente indispensável para o implemento e o funcionamento de uma concorrência normativa entre os Estados ${ }^{4}$. Dela resulta o forte progresso do método do reconhecimento das situações jurídicas regularmente criadas no estrangeiro a fim de restringir o emprego da regra de conflito de leis no espaço no tratamento das relações privadas internacionais ${ }^{5}$.

3 Essa lei foi promulgada, inter alia, para romper com os excessos e abusos cometidos pelos tribunais portugueses na aplicação contra legem do direito romano (fonte de direito subsidiário conforme às Ordenações Filipinas de 1603) e pela communis opinio doctorum dos pós-glosadores. Para esse fim, condicionou a aplicação subsidiária do direito romano às leis do Reino à sua conformidade com a recta ratio, que se baseava na lei natural e no usus modernus pandectarum que o direito das gentes tinha unanimemente estabelecido para governar e dirigir todas as nações civilizadas. Além disso, a Lei da Boa Razão autorizou a aplicação subsidiária, para assuntos políticos, econômicos, comerciais e marítimos, das leis das nações cristãs, iluminadas e cultivadas. Assim, essa lei concedeu aos juízes a possibilidade de fazer comparações jurídicas para justificar suas decisões e, consequentemente, de modernizar o direito português à luz das novas abordagens europeias do direito da época. Adotada em 18 de Agosto de 1769, a Lei da Boa Razão permaneceu em vigor em Portugal até 1866 e no Brasil até 1916, datas que correspondem à de adoção de um código civil por esses dois países, respetivamente. Cf. J. H. Correia Telles, Commentario crítico á Lei da Boa Razão, em data de 18 de agosto de 1769, Lisboa: Typografia de N. P. de Lacerda, 1824.

${ }^{4}$ V. H. Muir Watt, "Concurrence d'ordres juridiques et conflit de lois de droit privé”, Mélanges P. Lagarde, Dalloz, 2005, p. 615-633. Sobre as concepções de concorrência utilizadas no campo jurídico, v. dentre outros, S. Harnay et J.-S. Bergé, "Concurrence entre règles juridiques et construction européenne : à propos de l'analyse économique du droit", Etudes en l'honneur du professeur Michel Bazex, Litec, 2009, p. 15-25; "Les analyses économiques de la concurrence juridique : un outil pour la modélisation du droit européen”, Revue internationale de droit économique 2-2011, t. XXV, p. 165-192. Globalmente, v. J. du Bois Gaudusson e F. Ferrand (dir.), La concurrence des systèmes juridiques, PUAM, 2008; R. Sefton-Green et L. Usunier (dir.), La concurrence normative, Mythes et réalités, Paris: Société de législation comparée, 2013.

$5 \quad$ V., em último lugar, Y. Lequette, Les mutations du droit international privé : vers un changement de paradigme? Cours général de droit international
Nesse contexto, no qual o direito comparado é sistematicamente mobilizado ${ }^{6}$, surge, inevitavelmente, a dúvida sobre a maneira como ele servirá aos apetites reformadores do legislador, quando não àqueles do juiz. Direito e comparação compartilham uma estreita relação com a retórica. Quais são hoje as funções retóricas da comparação de diferentes sistemas jurídicos? Heurística, pedagógica, hermenêutica, persuasiva? É possível conceber a comparação jurídica sem uma finalidade crítica do direito contemporâneo?

Em causa, o bom uso - a boa razão - do direito comparado. Em face dos desafios postos pelas ideias atuais de modernização do direito, a comparação pode revelar uma excelente ocasião de reflexão sobre a pertinência das soluções estrangeiras de sua eventual transposição alhures.

Nessa perspectiva, a comparação jurídica apresenta-se de forma ambivalente: ela justifica e ao mesmo tempo interpela a modernização projetada.

Se, todavia, o direito comparado intervém tradicionalmente no discurso político como argumento de potencial impacto para justificar a modernização do direito - quer pelo legislador, quer pelo litigante, quer pelo juiz, quer pela doutrina - , raramente interfere como contra-argumento no momento de sopesar a pertinência e a oportunidade da modernização à luz do direito d'alhures.

Por essa razão, como um dos suportes das atuais ideias de modernização do direito (2), a comparação jurídica pode emergir como um ato de prudência diante das ideias propulsoras da modernização almejada (3).

\section{A comparação jurídica como suporte das ideias de modernização}

A comparação jurídica tornou-se um importante suporte das ideias que justificam a modernização do direito: não há hoje reforma que não busque, no direito comparado, um argumento de peso para amparar esta ou aquela política legislativa, refutar esta ou aquela solução...

\section{privé, RCADI, t. 387 (2017).}

6 Para um excepcional exemplo em matéria societária, v. G. Cerqueira, "Libre circulation des sociétés en Europe: concurrence ou convergence des modèles juridiques", Revue trimestrielle de droit européen, 1-2014, p. 7-38. 
Para além da hipercomplexidade do objeto de comparação neste início de século ${ }^{7}$, resta apreciar sua incidência sobre as duas ideias, relativamente autônomas, que a noção de modernização contém hoje. Por um lado, a comparação ampara uma adaptação do direito às sensibilidades do tempo (2.1); por outro lado, ela auxilia a adaptação do direito à atual concorrência internacional das ordens jurídicas (2.2).

\subsection{Suporte à adaptação do direito às sensibilidades do tempo}

A comparação ampara uma adaptação do direito às sensibilidades do tempo para satisfazê-las no plano jurídico. A emergência do fundamento afetivo do casamento no direito francês pode, primeiramente, ilustrar o fenômeno (2.1.1). Nessas situações, no entanto, o amparo pode, em seguida, revelar-se insuficiente (2.1.2).

\subsubsection{Ilustração: o casamento homossexual na França}

Em oposição à concepção original do casamento, a lei francesa de 17 de maio de 2013 que possibilita o casamento às pessoas de mesmo sexo traz um fundamento novo para justificar a reforma. Com efeito, o sentimento é o novo alicerce do casamento ${ }^{8}$.

Embora a modernização do direito tenha sempre se ancorado na comparação jurídica, a exemplo da codificação civil francesa de 1804 (v. J.-L. Sourioux, "Notule sur le droit comparé dans les travaux préparatoires du Code civil des Français", in De tous horizons. Mélanges Xavier Blanc-Jouvan, Paris: Société de législation comparée, 2005, p. 159-163) e da codificação comercial brasileira de 1850 (v. I. de Aguilar Vieira e G. Cerqueira, "L'influence du Code de commerce français au Brésil (Quelques remarques sur la commémoration du bicentenaire du Code français de 1807)", Revue internationale de droit comparé, 1-2007, p. 27-77), essa ancoragem apresenta hoje dificuldades quase inexistentes até meados do Século XX. De um lado, o comparatista é confrontado à complexidade do objeto de comparação, marcado, primeiramente, pelo pluralismo jurídico (transformação brutal da representação dos sistemas de direito sujeitos à comparação) e, em seguida, pela dificuldade de escolha dos modelos de referência. De outro lado, o comparatista vê-se diante de um comportamento ambíguo dos processos de modernização do direito nos dias de hoje: primeiramente, uma tendência à confluência das iniciativas de modernização parece emergir da ideologia dos direitos fundamentais; em seguida, uma tendência à concorrência normativa anima as grandes reformas do direito privado atuais. Para aprofundar a questão, v. B. Fauvarque-Cosson, "Deux Siècles d'évolution du droit comparé", Revue internationale de droit comparé, 3-2011, p. 527-540; cf. a obra De tous horizons. Mélanges Xavier Blanc-Jouvan, op. cit., passim.

8 G. Choisel, 'D'un changement de définition à un droit en at-
Como sintetizou um autor, "[bem] longe de sua primeira função jurídica, o casamento é doravante '[fundado] sobre o amor' que ele deve 'institucionalizar'. Assim, sua função é a de '[manifestar] o reconhecimento pela sociedade do amor existente entre um casal e do compromisso que cada um assume em relação ao outro'. E o relator do projeto de lei precisou que 'o casamento passou do estatuto de contrato-instituição organizando a filiação no seio do casal, para aquele de união de dois indivíduos enamorados"”.

Fundado doravante sobre o reconhecimento dos sentimentos, "não admitir o casamento para os casais de mesmo sexo seria um retorno a uma hierarquização dos amores e a uma discriminação em relação aos amores homossexuais. Essa nova função da união matrimonial, desejada pelo legislador, explica também porque não seria suficiente o estabelecimento de um regime contratual assegurando às uniões estáveis de pessoas de mesmo sexo uma comunidade de interesses e uma possibilidade de proteção patrimonial do cônjuge sobrevivente. Com efeito, nem o Pa.C.S. nem uma eventual união civil implicaria um objetivo sentimental: somente a abertura do casamento aos casais de mesmo sexo poderia permitir o pleno reconhecimento jurídico dos sentimentos entre pessoas de mesmo sexo e '[assim colocar] fim a uma desigualdade de direito""10.

Em sua exposição de motivos, o legislador francês recorreu às experiências jurídicas de outros países, como Bélgica, Espanha, Noruega, Países Baixos, Portugal e Suécia ${ }^{11}$ para justificar não apenas a pertinência, mas a necessidade de romper com o imobilismo jurídico ${ }^{12}$ doravante incompatível com uma nova realidade social, em

tente de reconstruction. Réflexions sur l'étendue des conséquences juridiques de la loi ouvrant le mariage aux couples de personnes de même sexe", Revue trimestrielle de droit civil, 3-2015, p. 505-516 (reproduzido em língua portuguesa na Revista de Direito Civil contemporâneo, vol. 11 (2017), p. 299 et seq., tradução de I. de Aguilar Vieira, oportunamente utilizada nas citações a seguir da versão original deste artigo). 9 Idem, p. 510 e bibliografia citada.

10 Ibid., p. 511 e bibliografia citada.

11 Cf. Projet de loi ouvrant le mariage aux couples de personnes de même sexe - Étude d'impact, novembre 2012, ponto 1-3 - "Éléments de droit comparé" e ponto 4 - "Impact sur les droits des femmes". Disponível em: http://www.assemblee-nationale.fr/14/projets/ p10344-ei.asp\#P445_49423 (consultado em 7 de julho de 2019).

12 Até o advento da lei de 2013, nenhuma jurisdição havia estendido aos casais homossexuais a aplicação dos textos relativos ao casamento. Pelo contrário, todas recusaram tal extensão (Cass. $1^{\text {re }}$ Civ., 13 de março de 2007, n. ${ }^{\circ}$ 05-16.627 ; Cons. const., 28 de janeiro de 2011, Decisão 2010-92 QPC ; CEDH, 24 de junho de 2010, Schalk et Kopf c/ Autriche, processo n. $\left.{ }^{\circ} 30141 / 04\right)$. 
longa escala determinada por uma sensibilidade pessoal.

Graças a essa nova definição do casamento a partir do sentimento amoroso, "o legislador pôde unificar a situação de todos os casais e, consequentemente, não mais rejeitar a igualdade jurídica em nome de suas diferenças de fato" ${ }^{\prime 3}$.

Consagrada no exterior, a solução importada na França apareceria, assim, como resposta adequada para satisfazer pretensões individualistas. Ela pode, no entanto, revelar as insuficiências do argumento comparatista.

\subsubsection{A insuficiência do suporte}

A insuficiência do suporte comparatista provém da utilização oportunista da experiência jurídica estrangeira pelo discurso modernizador, notadamente quando voltado para satisfazer sensibilidades individuais. Nesse caso, os modelos são escolhidos tão somente em razão de seu significado político, social e ideológico. A insuficiência revela-se na carência de soluções satisfatórias às questões de alta complexidade que a modernização ambicionada pode suscitar.

Tomando como base o exemplo do casamento homossexual na França, o legislador invocou a evolução do direito de alguns países para confortar sua proposição. Após enumerá-los, limitou-se, todavia, a afirmar, em relação à legislação dos seis países europeus que serviram de base aos seus estudos, que "o regime aplicável ao casamento entre pessoas de mesmo sexo é idêntico àquele aplicado ao casamento entre pessoas de sexo diferente" ${ }^{14}$. Nenhuma análise de fundo foi, no entanto, fornecida sobre a compatibilidade, naqueles países, da solução de princípio - admissão do casamento às pessoas de mesmo sexo - com o regime que resulta da natureza jurídica do casamento. Dito de outra maneira, o projeto não demonstra retirar quaisquer lições do estudo comparativo realizado, embora certamente existam...

A questão essencial é de saber como integrar, juridicamente, o amor no casamento. Com efeito, posto como novo fundamento jurídico do matrimônio, o amor deve, necessariamente, ser apreendido pelo direito. Ora, o legislador francês não encarou esse problema. Referiu-se à existência alhures da nova concepção para

13 G. Choisel, "D'un changement de définition à un droit en attente de reconstruction", loc. cit., p. 511 e bibliografia citada.

14 Cf. Projet de loi ouvrant le mariage aux couples de personnes de même sexe - Étude d'impact, novembre 2012, loc. cit., ponto 1-3. motivar sua política legislativa sem, contudo, oferecer respostas a uma série de questões resultantes de sua escolha. Talvez porque, em lugar algum, as respostas a essas questões sejam evidentes ou satisfatórias!

Duas questões ilustram a dificuldade. Em primeiro lugar, se o amor se torna fundamento do casamento, como apreciar a validade do matrimônio por esse prisma? Um autor sugeriu imaginar, por exemplo, uma concepção inovadora da causa: "não mais fundada sobre a ideia de dívida e liberada da tradicional dicotomia contrato a título oneroso/contrato a título gratuito, própria à sua acepção de finalidade imediata, a causa se expressaria no amor que apareceria então como a razão do compromisso de viver juntos no âmbito de um contrato dotado de um estatuto de ordem pública. Entendido no sentido que o controle de licitude dava à causa até a reforma de 2016, o amor seria doravante o motivo determinante, aquele "que leva à conclusão do contrato"15. Assim, "ao contrário da jurisprudência, tratar-se-ia de aplicar a teoria subjetiva da causa ao casamento definido como um contrato típico - aquele no seio do qual 'a causa recebe uma definição jurídica para todas as partes [que] são movidas por uma finalidade conhecida, unida a uma estrutura determinada'. Em outros termos, a validade do casamento seria condicionada à existência de uma causa final única: o reconhecimento e a consagração do sentimento amoroso. Além disso, essa integração da causa ao casamento permitiria fazer evoluir o fim da união. Com efeito, no momento em que se busca simplificar os procedimentos de divórcio, a utilização da causa poderia permitir a aplicação de uma caducidade do casamento pelo desaparecimento da causa se os sentimentos deixassem de existir" ${ }^{\prime 16}$. Porém, numa altura em que a causa perde suas cartas de nobreza no direito francês ${ }^{17}$, torna-se difícil prever a integração legal do amor entre as condições de validade da união matrimonial, ainda que paradoxalmente dela tenha se tornado

15 G. Choisel, "D'un changement de définition à un droit en attente de reconstruction", loc. cit., p. 511 e bibliografia citada.

16 Idem.

17 No seu objetivo de simplificação e de modernização, a reforma do direito francês dos contratos, do regime geral e da prova das obrigações, realizada em 2016, retirou a noção de causa das condições de validade dos contratos (cf. novo artigo 1128, Code civil). Suas funções são hoje asseguradas em parte pelas noções de objetivo contrato (but du contrat, cf. novo artigo 1162 do Code civil) ou de motivo (cf. novo artigo 1135, Code civil). A propósito, v. dentre uma vasta literatura, $\mathrm{O}$. Deshayes et alii, Réforme du droit des contrats, $d u$ régime general et de la preuve des obligations. Commentaire article par article, $2^{\mathrm{e}}$ éd., LexisNexis, 2018, p. 197 et seq. 
fundamento!

Em segundo lugar, e mais fundamentalmente, qual tratamento jurídico reservar ao amor no âmbito do casamento renovado? Como lembra um autor: "[f]undar uma igualdade jurídica sobre uma igualdade de sentimentos e dar ao direito a função de reconhecer o amor, reclama [defini-lo] e inquerir sobre a eventual circunscrição de seu reconhecimento. Com efeito, em que medida a ordem pública pode declarar um sentimento aceitável e legítimo? Pode ainda o casamento, por exemplo, excluir os amores incestuosos ou bígamos? Destacada de considerações fisiológicas e morais, a capacidade de consentir poderia então ser reduzida à simples capacidade jurídica" ${ }^{18}$.

Talvez as respostas a essas questões provenham de uma ginástica intelectual à qual são afeitos os ideólogos. São, porém, manifestos os objetivos do modernizador que se determina segundo às circunstâncias do momento. Como adverte um autor, "[a] nova definição do casamento inscreve-se, [...], numa lógica dos direitos assexuados nos quais a orientação sexual decorre apenas de uma escolha individual: o casamento 'é doravante concebido, vivido, pensado, pelos indivíduos e pela sociedade como um estatuto do casal e não como o ato fundador de uma família'. A filiação aparece, assim, como destacada do casamento, cuja paternidade não é mais uma consequência"19.

A dificuldade em responder as questões supracitadas revela que a atenção a uma necessidade não implica $\mathrm{O}$ dever de fundar um direito. A referência ao direito comparado para demonstrar que a modernização fundada na necessária satisfação dos sentimentos individuais é possível, porque já realizada alhures, parece não bastar em si. Por quê ? Porque (tanto aqui, como ali, como acolá) o postulado individualista é inapto a responder aos problemas jurídicos ${ }^{20}$. Para um autor, esse "postulado se recusa a considerar a sociedade como um todo e o direito como um instrumento de regulação de suas interações" 21 ; o postulado individualista considera o indivíduo "como um ser isolado, dotado de um estoque de prerrogativas jurídicas: o direito se torna um fenômeno de realização individual diante do qual apenas

\footnotetext{
18 G. Choisel, "D'un changement de définition à un droit en attente de reconstruction", loc. cit., p. 511.

19 Ibid., p. 512 e bibliografia citada.

20 R. Libchaber, "L'ouverture de l'assistance médicale à la procréation à toutes les femmes", loc. cit., p. 1880.

21 Ibid.
}

restaria a se inclinar" 22 . Blaise Pacal já o afirmava em seus Pensamentos: "[s]obre qual base (o homem) fundará a economia do mundo que ele quer governar? Sobre o capricho de cada indivíduo? Que confusão!" ${ }^{23}$. Confusão... outra não é a conclusão à qual chegou parte da doutrina francesa sobre as mudanças operadas pela lei de $2013^{24}$.

Assim, mobilizado para responder às sensibilidades do tempo, o direito comparado pode conter insuficiências estruturais que serão igualmente transportadas ao direito modernizado à sua luz. Quid quando suporte à adaptação do direito à concorrência normativa?

\subsection{Suporte à adaptação do direito à concorrência internacional das ordens jurídicas}

A comparação jurídica auxilia uma adaptação necessária do direito para enfrentar a atual concorrência normativa entre os Estados. Nessa perspectiva, a comparação é, primeiramente, conduzida para tornar o direito atrativo internacionalmente (2.2.1). Mas, em seguida, a busca pela atratividade pode conduzir a um impasse: modernizar para distinguir-se dos demais direitos ou para alinhar-se aos mais competitivos? (2.2.2).

\subsubsection{O objetivo de atratividade jurídica}

A comparação é hoje conduzida para tornar o direito economicamente atrativo no plano internacional. Não fora este o segundo dos principais objetivos da reforma em 2016 do direito francês dos contratos? $?^{25} \mathrm{O}$

22 Ibid.

23 Les pensées de Pascal, reproduites d'après le texte autographe, disposées selon le plan primitif et suivies des Opuscules / édition philosophique et critique, enrichie de notes et précédée d'un Essai sur l'apologétique de Pascal, par A. Guthlin, Paris: P. Lethielleux, 1896 , p. 70.

24 Cf. M. Fabre-Magnan, La gestation pour autrui. Fictions et réalité, Fayard, 2013 ; da mesma autora, "L'impossibilité d'une gestation pour autrui 'éthique' ", in Archives de Philosophie du Droit - La famille en mutation, t. 57, 2014, p. 465-484; G. Choisel, “D'un changement de définition à un droit en attente de reconstruction", loc. cit., passim. Essa confusão faz parte de um projeto ideológico: Y. Lequette, "L'ouverture du mariage aux personnes de même sexe : clarification et réflexions", in D. Mazeaud et Y. Lequette (dir.), L'ouverture du mariage aux personnes de même sexe, Éd. Panthéon-Assas, 2014, p. 13 et seq.; e M. A. Frison-Roche, "Une famille à sa main", Archives de Philosophie du Droit - La famille en mutation, precitado, p. 249-265.

25 Cf. Rapport au Président de la République relatif à l'ordonnance n. ${ }^{\circ}$ 2016-131 du 10 février 2016 portant réforme du droit des 
Direito tendo se tornado um produto de mercado, é natural que a noção de atratividade se introduza no campo das reformas modernizantes! Sintomática a esse respeito a existência na Universidade Sorbonne Paris Nord de um Instituto de pesquisa por um direito atrativo (IRDA) ou ainda, na Universidade de Reims, de um Centro de estudos jurídicos sobre a eficiência dos sistemas jurídicos continentais (Cejesco).

Modernizar, pois, para ser mais atrativo ${ }^{26}$. Nessa relação de causalidade, o direito comparado é chamado a alimentar a concorrência normativa.

Essa concorrência resulta do fato de que os legisladores nacionais ou regionais atuam para manter e atrair empresas e negócios para o território de seus Estados. Alguns fatores contribuem para a emergência dessa concorrência.

Em primeiro lugar, as leis nacionais estão sujeitas à arbitragem por parte de agentes privados (arbitragem regulamentar) que, por estarem autorizados a fazê-lo, dispõem de uma escolha de lei a fim de minimizar os custos das suas operações. De fato, as pessoas podem hoje escolher a lei nacional ${ }^{27}$ que convenha mais economicamente, justificando, assim, a expressão law shopping. Essa liberdade de escolha de lei é acompanhada de uma liberdade cada vez mais ampla de escolha de foro $^{28}$, o que dá lugar igualmente a uma concorrência internacio-

contrats, du régime général et de la preuve des obligations (JORF $n^{\circ} 0035,11$ février 2016, texte n. ${ }^{\circ}$ 25). V. L. Usunier, "A contribuição do direito comparado à reforma do direito francês das obrigações", in G. Cerqueira e C. Lima Marques (dir.), A função modernizadora do direito comparado - 250 anos da Lei de Boa Razão, São Paulo: YK Editora 2020 (no prelo); da mesma autora, "L'attractivité internationale du droit français au lendemain de la réforme du droit des contrats, ou le législateur français à la poursuite d'une chimère", Revue trimestrielle de droit civil, 2-2017, p. 343-349. Igualmente crítico sobre os resultados da reforma através do prisma da atratividade: Ch. Larroumet, "Le mythe de l'attractivité du droit civil français", in Liberté, justesse, autorité. Mélanges en l'honneur du professeur Laurent Aynès, Paris: LGDJ, 2019. 26 V. Ph. Delebecque, "'L'attractivité' du droit français : un mot d'ordre dépourvu de sens?", in Mélanges en l'honneur du professeur Laurent Aynès, op. cit., p. 185 et seq.

27 Cf. por exemplo, artigo 3 do Regulamento (CE) n ${ }^{\circ}$ 593/2008 do Parlamento Europeu e do Conselho, de 17 de Junho de 2008, sobre a lei aplicável às obrigações contratuais (Roma I) ; artigo 2 da Convenção da Haia de 1955 sobre a lei aplicável aos contratos de compra e venda internacional de mercadorias ; o artigo 7 da Convenção interamericana de 1994 sobre a lei aplicável aos contratos internacionais.

28 Cf. por exemplo, artigo 25 do Regulamento (UE) n. ${ }^{\circ} 1215 / 2012$ do Parlamento Europeu e do Conselho, de 12 de dezembro de 2012, relativo à competência judiciária, ao reconhecimento e à execução de decisões em matéria civil e comercial ; artigo 5 da Convenção da Haia de 2005 sobre os acordos de eleição de foro. nal de jurisdições nacionais (e logo a outro tipo de law shopping negativo - escolha de foros onde não há leis de polícia em determinadas matérias).

Em segundo lugar, porque têm algo a ganhar, ou a perder, das empresas que desenvolvem (ou não) as suas atividades sob o império da sua legislação, os Estados investem numa política legislativa de atração de empresas e investimentos (concorrência regulamentar) ${ }^{29}$. Tomando como exemplo a União Europeia, a concorrência normativa diz hoje respeito não apenas às matérias próprias aos negócios, como a lex societatis e a lex contractus, mas também àquelas para as quais, tradicionalmente, não se permitia a escolha de lei, como a matéria sucessória ${ }^{30}$ ou matrimonial ${ }^{31}$ ! A título de exemplo, uma reforma da reserva hereditária inspirada nos sistemas de common law é atualmente preconizada pelo Governo francês. Os argumentos que justificaram a criação da parte não disponível em Roma (a legítima romana) e a sua consagração no Código Civil de 1804 são hoje postos em causa em favor de argumentos econômicos: a base moral da reserva hereditária estaria em oposição a uma transformação da sociedade, em que o interesse econômico prevalece cada vez mais sobre o interesse comum. Trata-se de privilegiar a circulação do capital a fim de assegurar uma melhor alocação de recursos privados num mercado liberalizado ${ }^{32}$. A ideia de atratividade econômica do

29 Cf. G. Cerqueira "Libre circulation des sociétés en Europe: concurrence ou convergence des modèles juridiques", loc. cit., p. 16-17.

30 Cf. art. 22 do Regulamento (UE) n. ${ }^{\circ}$ 650/2012 do Parlamento Europeu e do Conselho, de 4 de julho de 2012 , relativo à competência, à lei aplicável, ao reconhecimento e execução das decisões, e à aceitação e execução dos atos autênticos em matéria de sucessões e à criação de um Certificado Sucessório Europeu.

31 Cf. art. 5 do Regulamento (UE) n. ${ }^{\circ}$ 1259/2010 do Conselho, de 20 de Dezembro de 2010 , que cria uma cooperação reforçada no domínio da lei aplicável em matéria de divórcio e separação judicial. 32 Os argumentos econômicos são utilizados num contexto normativo e jurisprudencial de enfraquecimento da reserva. De fato, uma reforma legislativa de 2001 abriu a propriedade a terceiros através da extensão da reserva ao cônjuge sobrevivente, enquanto uma reforma legislativa de 2006, ao excluir os ascendentes, "fez da reserva a extensão post mortem da obrigação de apoio" (R. Libchaber, "Des successions en quête d'avenir", Revue trimestrielle de droit civil, 2016, p. 729-750). Logicamente, no contexto da sucessão internacional, a Corte de Cassação considerou que a reserva só poderia constituir um princípio essencial do direito francês se permitisse evitar que os herdeiros merecessem uma proteção especial por causa da sua idade, situação ou estado de saúde sem recursos (Cass. $1^{\text {re }}$ Civ., 27 de setembro de 2017, n. ${ }^{\circ}$ 16-17.198 e n. ${ }^{\circ}$ 16-13.151; Cour de cassation, Rapport annuel 2018, p. 161-163). Para justificar essas decisões, a Corte invoca o desenvolvimento do direito da reserva em direito interno, em particular a possibilidade, desde 2006, de um herdeiro necessário renunciar a uma eventual ação de redução, a inconstitucionalidade do droit de prélèvement, declarado pelo Conselho 
direito francês está bastante presente nessa preconização que visa igualmente conter a fuga de grandes fortunas em direção a países que admitem a plena liberdade testamentária, como revelou a recente jurisprudência francesa nessa matéria.

Orientadas pela ideia de atratividade, as reformas nacionais na Europa tocam assim ramos tão diversos quanto o direito das sociedades, o direito das obrigações, o direito falimentar, o direito da arbitragem, o direito das garantias, o processo civil, o direito de família e das sucessões e, até mesmo, a função e a metodologia dos tribunais superiores.

Nesse contexto de reformas "atrativas", surge um impasse reformador comparatista: buscar a originalidade ou a uniformidade?

\subsubsection{0 impasse da atratividade jurídica}

A atratividade internacional das ordens jurídicas pode ser fundada sobre as propriedades específicas do direito a modernizar ou sobre o abandono dessas especificidades. Para qual direção as reformas justificadas pelo direito comparado têm apontado?

A resposta nem sempre é evidente. Ela pode mesmo variar segundo a análise diga respeito a um campo específico do direito de um país ou à sua globalidade.

Tomemos a França como exemplo, em razão de sua importância como modelo jurídico original. Se considerarmos, apenas, o direito francês de sociedades, a resposta é ambivalente: às vezes há (ou não) perda de originalidade $^{33}$. Em contrapartida, considerando-se o direito francês como um todo, a resposta pode ser mais acentuada: para muitos autores, o grande vento de reformas tem afetado a especificidade do sistema jurídico, levando-o à perda de sua identidade para tornar-se competitivo à luz do direito comparado ${ }^{34}$.

Se a supressão da noção de causa do direito fran-

Constitucional em 2011, e o Regulamento Europeu n. ${ }^{\circ}$ 650/2012 de 4 de Julho de 2012, que permite uma opção de lei sucessória. V. G. Cerqueira e G. Choisel, "La reserve héréditaire en droit français: vers la renonciation à un héritage romain?", Вестник Омского университета. Серия: Право [Mensageiro da Universidade de Omsk. Série: Direito], vol. 17, 2020, n. ${ }^{\circ} 2$ (no prelo).

33 G. Cerqueira "Libre circulation des sociétés en Europe: concurrence ou convergence des modèles juridiques", loc. cit., p. 15 et seq. 34 S. Piédelièvre, "Du passé, ne faisons pas table rase", Recueil Dalloz 2019, p. 1547-1548. cês dos contratos pela reforma de 2016 ilustra perfeitamente o fenômeno, outro exemplo será aqui preferido: a reforma da redação e da motivação dos acórdãos da Corte de Cassação. A reforma dessa genuína arte judiciária francesa permite apreciar o grau de desnaturação possível de um direito em nome da atratividade internacional.

Do ponto de vista formal, os acórdãos são conhecidos por sua concisão, amparada na técnica dos Attendus (considerandos) $)^{35}$. Todavia, uma reforma em curso $^{36}$ conduziu à "morte dos attendus" 37 e da frase única a partir de $1^{\circ}$ de Outubro de $2019^{38}$. Desde então, as decisões passam a conter três partes, claramente identificadas: fatos e processo, exame dos fundamentos de recurso e resposta da corte (motivação e dispositivo). Para além, as sentenças dividir-se-ão doravante em duas categorias: as que são importantes e as que não o são. Os critérios de importância são: mudança de jurisprudência, questão legal de princípio, violação de direito ou de princípio fundamental, controle de proporcionalidade, unificação da jurisprudência, desenvolvimento do direito, questão prejudicial. Apenas a primeira categoria beneficiará o

35 Consideração que dá origem a um julgamento e é declarada em uma frase que começa com as palavras Attendu que. Cada attendu formula um ponto de fato ou de direito. O Vocabulário Jurídico define o Attendu como: "Motivo (repetitivo) de uma demanda ou de uma decisão de justiça (que tira seu nome da fórmula pela qual ele começa : "attendu que") que, em um estilo monofrásico, tradicional (hoje em concorrência - ou em combinação com o estilo direto), é o elemento de uma série destinada a desenvolver a exposição do caso e terminada, antes do enunciado do dispositivo, pela fórmula "por esses motivos"; cada attendu enuncia um ponto de fato ou de direito, bem como, às vezes, as fases do processo". G. Cornu (dir.), Vocabulaire juridique, $13^{\mathrm{a}}$ ed., Paris: Puf, 2020 ( $V^{\circ}$ Attendu).

36 V. not. B. Louvel, "Pour exercer pleinement son office de Cour suprême, la Cour de cassation doit adapter ses modes de controle", JCP G, 2015, p. 1122 ; Rapport de la Commission de réflexion sur la réforme de la Cour de cassation, avril 2017 (disponível em: https://www.courdecassation.fr/cour_cassation_1/reforme_cour_7109/); J. Théron, "Sublimer l'essence de la Cour de cassation ? À propos du rapport de la Commission de réflexion sur la réforme de la Cour de cassation - Aperçu rapide", JCP G, n. ${ }^{\circ}$ 24, 12 juin 2017, p. 1139-1142. V. ainda P. Jestaz, J.-P. Marguénaud, C. Jamin, "Révolution tranquille à la Cour de cassation", Recueil Dalloz, 2014, p. 2061 ; B. Haftel, "Libres propos sur l'avant-projet de réforme de la Cour de cassation et la fonction du juge", Recueil Dalloz 2015, p.1378 ; Regards d'universitaires sur la réforme de la Cour de cassation, JCP G - suppl. au n. ${ }^{\circ} 1-2$, janv. 2016 ; F. Zenati-Castaing, "La juridictionnalisation de la Cour de cassation", Revue trimestrielle de droit civil, 3-2016, p. 511 et seq.

37 V. O. Deshayes, "La mort des attendus", Revue des contrats, 4-2018, p. 531.

38 O leitor consultará utilmente os documentos relativos a esse aspecto da reforma, elaborados pela Corte e disponíveis em : https://www.courdecassation.fr/institution_1/reforme_cour_7109/ reformes_mouvement_8181/redaction_decisions_9223/ 
que se chama uma motivação desenvolvida ${ }^{39}$. As soluções não privilegiadas serão, no entanto, mencionadas, quando tiverem sido seriamente discutidas durante a deliberação, justificando as razões de sua exclusão. Em caso de alteração da jurisprudência, serão indicados os precedentes.

Ênfase foi colocada na legibilidade e na inteligibilidade dos acórdãos não apenas para satisfazer às exigências de explicação pedagógica persuasiva e de segurança jurídica, mas também para garantir uma melhor “difusão do direito francês no campo jurídico internacional"40. Espera-se, assim, pelo menos, em teoria, por termo a discussões intermináveis sobre o que a Corte quis dizer.

Haverá padronização das decisões da Corte de Cassação. Essa reforma inspirou-se na forma como as Cortes europeias redigem suas decisões, que se tornam, pouco a pouco, o modelo a respeitar. Essa preocupação com a pedagogia, tanto para os juízes de primeira instância quanto para os litigantes, é sem dúvida o prelúdio de uma reforma mais ampla, desejada por alguns, que levaria a um redirecionamento da atividade da Corte para um número menor de casos, transformando-a em uma espécie de Suprema Corte ${ }^{41}$.

Que restará da especificidade da Cassação francesa? A concisão de suas decisões tinha por vezes suas insuficiências ${ }^{42}$, porém muitas são as suas virtudes, notadamente a de constituir uma sofisticada forma de raciocínio ${ }^{43}$ e servir de material altamente útil para o ensino do direito nas universidades por meio do clássico e quão temido exercício de "commentaire d'arrêt". Algumas

\footnotetext{
39 Sobre esse aspecto da reforma, v. G. Cerqueira, "La justiciabilité du droit souple au regard de la réforme de la Cour de cassation", in T. Hochmann et al. (dir.), Le contrôle juridictionnel du droit souple, Reims : EPURE, 2017, p. 137-173.

40 Cf. Le mode de rédaction des arrêts de la Cour de cassation change Dossier de presse. Disponível em : https://www.courdecassation.fr/ IMG///mode_de_redaction_01.07.19_v2.pdf

${ }^{41}$ Para uma crítica contundente, v. F. Zenati-Castaing, "La juridictionnalisation de la Cour de cassation", loc. cit., p. 511 et seq.

42 Denúncias e defesas pontuaram o curso das publicações após as primeiras críticas formuladas por R. Demogue (Notions fondamentales du droit privé. Essai critique pour servir d'intriduction au droit, LGDJ, 1911, p. 222) e a publicação do apelo de A. Touffait e A. Tunc em 1974: "Pour une motivation plus explicite des décisions de justice, notamment de celles de la Cour de cassation", Revue trimestrielle de droit civil, 1974, p. 487 et seq. Para uma visão completa deste fenômeno doutrinal: F. Malhière, La brièveté des décisions de justice (Conseil constitutionnel, Conseil d'État, Cour de cassation) - Contribution à l'étude des représentations de la justice, préf. D. Rousseau, Paris : Dalloz, 2013.

43 S. Piédelièvre, "Du passé, ne faisons pas table rase", loc. cit., p. 1548.
}

decisões do século XIX e início do século XX podem ser consideradas como modelos de clareza! Sem dúvida, como afirmou recentemente um Conselheiro honorário da Corte de Cassação, "a motivação condensada não é uma motivação hermética", assim como "a motivação breve evita a nocividade das proposições inúteis", para concluir que, se os desafios da modernidade reclamam um motivação acessível a todos tanto em termos de linguagem quanto de raciocínio, não há como contestar a inescapável tecnicidade da lei, tampouco renunciar procedimentos abreviados que, consagrados por uma fecunda tradição, exigem, apenas, um esforço razoável mas insubstituível por parte do leitor ${ }^{44}$. Para os mais céticos, nada garante que essas virtudes se reflitam na nova redação dos acórdãos da Corte de Cassação; ao contrário, a modernidade exige, necessariamente, uniformidade ${ }^{45}$. Consequência: antes modelo, o direito francês torna-se hoje um seguidor de tendências ${ }^{46}$.

As reformas justificadas com base no direito comparado para fins de concorrência normativa conduz a uma uniformização espontânea, realizando assim uma das funções atribuídas ao direito comparado pelos pais do comparatismo moderno. Isso tem levado alguns autores, todavia, a se perguntar se o grande vento da reforma que toca o direito francês, há alguns anos, não resultaria no desaparecimento das instituições e dos regimes que faziam a especificidade do sistema jurídico daquele país ${ }^{47}$.

A respeito das ocorrências supracitadas, verifica-se que, como suporte de uma modernização do direito orientada para satisfazer o individualismo, a comparação jurídica pode revelar insuficiências estruturais das soluções almejadas, ao passo que, voltada para justificar reformas motivadas pela política de atratividade internacional de uma dada ordem jurídica, a comparação pode levar à perda de sua identidade sem a garantia da melhoria prometida em contrapartida: estranha ambiguidade esta de buscar ser atrativo deixando de ser original ${ }^{48}$

Para contornar tais riscos, a comparação pode exercer um outro papel.

\footnotetext{
44 J.-P. Gridel, "La motivation aux défis de la modernité - Entre le Charybde de l'hermetisme et le Scylla du bavardage", JCP G, n. ${ }^{\circ}$, 2020, p. 242-249.

45 S. Piédelièvre, "Du passé, ne faisons pas table rase", loc. cit., p. 1548.

46 Ibid., p. 1547-1548.

47 Ibid., p. 1547-1548.

48 Assim, L. Usunier sobre a reforma de 2016 do direito francês dos contratos: "A contribuição do direito comparado à reforma do direito francês das obrigações", loc. cit.
} 


\section{A comparação jurídica como ato de prudência diante das ideias de modernização}

Com efeito, a comparação jurídica pode se apresentar como ato de prudência em face das ideias de modernização. Nessa perspectiva, convém, por um lado, oferecer algumas razões da prudência (3.1) e, por outro lado, esboçar o critério da prudência (3.2).

\subsection{Razões da prudência}

No sentido aristotélico, prudência é uma virtude intelectual prática que consiste em saber julgar bem o que permanece contingente: "uma disposição prática, acompanhada de uma regra verdadeira, concernente àquilo que é bom e ruim para o homem"49.

Transposta à política legislativa, a prudência aristotélica torna-se uma virtude do legislador em adotar leis visando promover o interesse comum ${ }^{50}$. Dito de outra maneira, e na linguagem corrente, é qualidade que leva o legislador a examinar as possíveis consequências dos seus atos para evitar erros ou perigos.

Aplicadas ao direito comparado, as razões da prudência são conhecidas. Primeiramente, "Verdade aquém dos Pirenéus, erro além" (3.1.1). Em seguida, "O mito do legislador estrangeiro" (3.1.2).

\subsection{1 "Verdade aquém dos Pirenéus, erro além"}

A conhecida assertiva de Pascal lembra que o que é uma verdade para um povo pode ser um erro para os outros $^{51}$.

Essa assertiva não é estranha ao comparatista advertido. Estava presente desde o início do direito comparado moderno. Por exemplo, ao definir largamente a lei como "relações necessárias que derivam da natureza das coisas" $" 52$, Montesquieu — sem aderir ao positivis-

\footnotetext{
49 Aristote, Éthique à Nicomaque, VI, 5, $1140 \mathrm{~b} 5$.

50 E como afirmou mui pertinentemente Marc Ancel em 1960, a noção de política legislativa pode ser entendida em sentido largo de sorte que ela não visa apenas o legislador mas também aqueles que são chamados a explicar a lei ou a aplicá-la: o juiz e o administrador ("Politique législative et Droit comparé", loc. cit., p. 18).

51 "Plaisante justice qu'une rivière borne! Vérité au deçà des Pyrénées, erreur au-delà" : Les pensées de Pascal, op. cit., p. 70.

52 De l'esprit des lois, Livre I, chapitre 1, op. cit., p. 123.
}

mo de Pascal (é direito apenas o direito positivo) ou ao universalismo abstrato do direito natural moderno considera que as leis relacionam-se com o conjunto de fatores que formam o espírito geral de um povo: "[a]s leis devem ser tão próprias ao povo para qual elas são feitas, que é praticamente um acaso se aquelas de uma nação podem convir a uma outra" ${ }^{3}$.

A propósito, é igualmente conhecida a confrontação entre Raymond Saleilles e Edouard Lambert no final do século XIX. Ao passo que Lambert entendia o direito comparado como um instrumento de aproximação das legislações para, superando a diversidade aparente entre elas, alcançar uma unificação do direito graças ao fundo comum que a comparação jurídica revela, Saleilles, sem prejuízo de sua visão universalista, não prescindia das especificidades de cada sociedade. Com efeito, precursor da noção de harmonização, Saleilles buscava, contudo, um "direito ideal relativo", definido como princípios comuns tidos por 'universais' — mas não imutáveis — que devem se adaptar às especificidades de cada sociedade. Para ele o direito comparado é um procedimento de crítica legislativa que permite "procurar, para uma dada instituição, não o que é o melhor em si, que era o próprio do direito natural, como era outrora entendido; nem mesmo o que seria, de todas as leis que a regem no estrangeiro, a melhor em termos de seus resultados, o que ainda seriam insuficientes, porque a aplicação de uma lei e os resultados que ela oferece dependem do estado social ao qual está adaptada; mas sim em que direção, de acordo com o conhecimento do direito estrangeiro, deve ser feita a orientação jurídica para um determinado estado social" ${ }^{54}$.

Essa prudência encontra-se hoje em diversos escritos comparatistas. Por exemplo, em sua homenagem a Gérard Cornu, Jean Pradel aborda as armadilhas do direito comparado ${ }^{55}$. Tomando como exemplo algumas aplicações em direito penal ${ }^{56}$, esse autor exorta o comparatista a conhecer o contexto do direito estrangeiro,

\footnotetext{
53 De l'esprit des lois, op. cit., p. 128.

54 R. Saleilles, "Conception et objet de la science du droit comparé", in Congrès international de droit comparé tenu à Paris du 31 juillet au 4 août 1900: procès-verbaux des séances, Paris: LGDJ, 1905, p. 167-189, p. 168.

55 J. Pradel, "Les pièges du droit comparé", Écrits en hommage de Gérard Cornu, Paris: Puf, 1994, p. 345-357.

56 Para um exemplo em direito constitucional, v. P. Gelard, "Quelques conseils au constitutionnaliste de droit comparé", Mélanges en l'honneur de L. Favoreu, Renouveau du droit constitutionnel, Paris: Dalloz, 2007, p. 705-711.
} 
notadamente os dados sociológicos - natureza e influência - , para evitar erros de compreensão dos termos e do conteúdo das regras estrangeiras estudadas e garantir assim uma comparação útil ${ }^{57}$. Para o autor, "O direito insere-se em uma cultura e é aplicado em função desta cultura. É dizer toda a importância do contexto para neutralizar as armadilhas do direito penal comparado".

O estudo do contexto para entender o texto será tanto mais importante quando a comparação tende a inspirar a modernização de um dado direito. Outra não é a advertência de Marc Ancel, que reclama do comparatista mais atenção à política legislativa do sistema estudado - o que teria faltado tanto à doutrina científica do comparatismo francês do início do Século XX, representada por R. Saleilles, E. Lambert e H. Lévy-Ullmann, quanto à nova Escola comparatista que lhe sucedera a fim de não tomar como um dado definitivo soluções de uma legislação eminentemente móvel. Espelho de uma sociedade, a política legislativa responde de maneira diferente a problemas às vezes idênticos a muitas sociedades ${ }^{58}$. Por conseguinte, a pesquisa comparativa, com fins de preparação de uma nova orientação da política legislativa de um país, permitirá estabelecer direções ainda mais precisas quando a análise for "além do texto estrangeiro" e captar "a corrente legislativa" que suscitou as direções privilegiadas no estrangeiro e recolocar estas últimas no contexto político-social onde se integram. Isso evitará, conclui o autor, tanto "modismos precipitados como objecções não razoáveis". ${ }^{59}$

Apesar desse apelo razoável à prudência, quantas não são as ocorrências em que comissões parlamentares e jurisdições superiores se contentam de sínteses comparativas preparadas apressadamente, muitas vezes apresentadas de modo quase-impressionista, do direito daquele ou daquele outro país, escolhidas a contento para amparar as orientações — seguidamente ideológicas - preconizadas ?0 $^{60}$

\footnotetext{
57 Para um esforço dessa natureza relativo ao exercício comparativo franco-brasileiro, v. G. Cerqueira, "Les données fondamentales pour la comparaison juridique en droit privé", in G. Cerqueira et alii. (dir.), Les frontières entre liberté et interventionnisme en droit francais et en droit brésilien, Paris: L'Harmattan, 2010, p. 67-149.

58 M. Ancel, "Politique législative et Droit comparé", loc. cit., p. 15. 59 Idem, p. 19.

60 Cf. Idem, p. 19. Para exemplos relativos à jurisprudência do Supremo Tribunal Federal brasileiro, v. a pertinente e corajosa análise crítica de C. Bastide Horbach "O direito comparado no STF: internacionalização da jurisdição constitucional brasileira”, Revista de Direito Internacional, Brasília, v. 12, n. 2, 2015 p. 193-210. Para um
}

A questão não é anódina. Ela revela aquilo que Jean Carbonnier viria a alcunhar de "o mito do legislador estrangeiro".

\subsection{2 "O mito do legis/ador estrangeiro"}

Em seus Ensaios sobre as leis de $1979^{61}$, o precursor da sociologia jurídica na França evoca 0 mito do legislador estrangeiro para precaver o legislador reformador. Para Carbonnier, o comparatista vulgarizado - por oposição ao comparatista erudito —, alimenta-se, em particular, dos paralelos estabelecidos pelos meios de comunicação social do tipo "o acionista americano é melhor protegido do que os franceses" ou que "a evasão fiscal é impossível em todo o lado exceto aqui": "[e]m uma época na qual a hiperintervenção legislativa não assusta mais, há uma lege ferenda na menor reportagem" ${ }^{2}$. Ainda para Carbonnier, "[n]as mãos de um governo — ou também da sua oposição - a invocação da legislação comparada é, muitas vezes, apenas um instrumento de propaganda. Estatísticas fragmentadas, isoladas e não interpretadas; uma sociologia do turismo: uma psicologia pela impressão - é tudo o que é preciso para creditar os milagres do modelo distante que se quer promover. Apenas resta à opinião pública seguir" ${ }^{\prime 33}$.

Para o jurisconsulto francês, trata-se de um fenômeno de influência dentre muitos outros estudados pelos psicólogos, dotado porém de originalidade: “[a]o invés de ser geralmente influenciado pela comunicação imediata, um-a-um, ele é construído sobre um padrão triangular: a persuasão não se exerce pelo próprio exemplo do persuasor, mas recorrendo ao exemplo de outros" ${ }^{64}$. Assim, explica Carbonnier, "[e]specialistas em publicidade descreveram essa técnica testemunhal, onde o creme dental é recomendado pelo uso alegado por celebridades com dentes brilhantes. Como é possível, pergunta por vezes o leigo, que terceiros tenham uma autoridade que se tenha recusado a conceder-se à outra parte? É

exemplo marcante de compreensão insuficiente do direito importado para fins de modernização, v. N. Nord, "A comparação jurídica: maneira privilegiada e contestada da modernização do direito na China”, in G. Cerqueira e C. Lima Marques (dir.), A função modernizadora do direito comparado - 250 anos da Lei de Boa Razão, São Paulo: YK Ediora, 2020 (no prelo).

${ }^{61}$ J. Carbonnier, Essais sur les lois, Paris: Defrénois, 1979, p. 117122.

62 Idem, p. 121.

63 Ibid., p. 121-122.

${ }^{64}$ Ibid., p. 122. 
que o terceiro, precisamente, presume-se ser imparcial, estranho ao debate sórdido de interesses que é o contrato; daí, por hipótese, os terceiros são como deuses. Ora, há nações nos mercados comerciais que são estrelas coletivas: o rótulo suíço é uma promessa de duração, a promessa japonesa de um preço modesto etc." ${ }^{65}$

E o mesmo se aplica aos mercados legislativos, adverte Carbonnier, tomando o autor de Do Espírito das leis como exemplo: "[q]uando Montesquieu quis vender uma constituição nos salões de Paris, não se enganou ao procurar uma referência na Inglaterra". E conclui: "querem liberalizar seu direito de família hoje ? Tragam modelos suecos..." 66

Em um contexto de política legislativa marcado pelo imperativo da atratividade internacional, o fenômeno descrito por Carbonnier acentua-se, provocando importante reação na doutrina: "o direito não deve ser o reflexo da moda ou de uma moda" ${ }^{\prime 67}$.

A prudência aqui é decisiva porque o modismo comparatista pode implicar a importação não apenas de regras, mas de verdadeiras correntes legislativas estrangeiras ou internacionais em países de estrutura por vezes profundamente diferentes, ainda que confrontados a problemas sociais e humanos semelhantes. Qual a garantia de uma recepção bem sucedida? Essa pergunta é ainda mais importante porquanto modelos jurídicos logo, de sociedade - circulam hoje em muitos países sem que se instaure um verdadeiro debate preliminar na sociedade sobre a pertinência e oportunidade de sua recepção.

Valiosa, assim, a lição de Carbonnier: o direito é um material frágil; como o vidro, ele quebra no transporte internacional.

Prudência, pois, para evitar que o vidro se quebre. Porém, segundo qual critério?

\subsection{Critério da prudência}

A busca pelo critério da prudência reclama, primeiramente, identificar o que desestabiliza o direito confrontado à questão de sua modernização. Trata-se do fator do critério. Em nossa perspectiva, esse fator é o

65 Ibid., p. 122.

66 Ibid., p. 122.

${ }^{67}$ P. Delebecque, "'L'attractivité' du droit français : un mot d'ordre dépourvu de sens?”, loc. cit., p. 193. progressismo (3.2.1). Em seguida, convém indicar o critério da prudência. Em face da deriva progressista, o conservadorismo poderia emergir como critério (3.2.2).

\subsubsection{O fator do critério: o progressismo}

O que desestabiliza o direito a modernizar pode ser identificado a partir da perspectiva progressista que subjaz à noção de modernização.

Como afirma Rémy Libchaber, "o postulado progressista caracteriza-se por tomar partido sempre a favor das 'novidades'. Essa concepção estima que a sociedade apenas será verdadeiramente humana quando desvinculada de todas as amarras de nosso passado natural. A antiga ordem deve necessariamente ser suprimida em seus últimos vestígios uma vez que ela encarna o passado e não o presente que está em vias de transformação para o futuro. O progressismo pecaria assim por uma espécie de confiança ingênua no progresso [...]" ${ }^{68}$.

Para essa retórica, explica, ainda, o civilista, "o essencial está em torno do binômio desconstrução-reconstrução. Importa desmontar as heranças do passado para mostrar que elas são intrinsicamente desprovidas de necessidade. Aquilo que é tomado como um dado natural seria apenas o resultado de uma construção histórica, logo, cultural. Dessa forma, qualquer ideia que tenha por base uma tradição poderá ser descontruída para ser reformulada de maneira a corresponder aos anseios atuais. A crítica aos elementos tradicionais justifica a adoção de uma solução substitutiva, pouco importa qual seja, com o benefício adicional de não ter que provar seus méritos" $"$. Por conseguinte, "[a nova solução] se impõe diante de uma tradição que tem sido duplamente questionada como contingente e injusta" ${ }^{70}$.

Pode o direito, contudo, deixar-se guiar pela fascinação do progresso e principalmente por princípios igualitaristas, a exemplo, na França, do casamento entre pessoas do mesmo sexo?

Em uma época na qual o progressismo é a base ideológica de pretensões individualistas, cujo grande devedor jurídico - sem que o saiba ou que tenha aceito a dívida - é a sociedade, torna-se preciosa a advertência de Pascal que convém reproduzir novamente: "[s]obre

\footnotetext{
68 R. Libchaber, "L'ouverture de l'assistance médicale à la procréation à toutes les femmes", loc. cit., p. 1881.

69 Idem.

70 Ibid.
} 
qual base (o homem) fundará a economia do mundo que ele quer governar? Sobre o capricho de cada indivíduo? Que confusão!" 71

Para evitá-la por ocasião do recurso ao argumento comparatista para a modernização ideológica de soluções perenizadas pela experiência humana, um critério de prudência é proposto.

\subsubsection{0 critério proposto: o conservadorismo}

Com efeito, a verdadeira prudência é aquele que não impede o enriquecimento do direito pela comparação jurídica, mas que opera tão somente uma abordagem crítica do argumento comparativo no debate sobre a modernização do direito de um país ou de um conjunto de países.

Esse critério poderia ser o conservadorismo. Para além das interpretações errôneas dessa noção ${ }^{72}$, a perspectiva conservadora não recusa a inovação, o progresso. Questiona, porém, suas vantagens e desvantagens admitindo como ponto de partida que a herança do passado possui uma consistência própria ${ }^{73}$. É, portanto, um método fundado na razão e não uma matriz ideológica, dotada de conteúdo próprio, abstrato, intransigente e imutável.

Ele opõe-se, com inteligência, à tragédia descrita por Raymond Aron: "é procurando substituir uma ordem teoricamente racional trabalhada por séculos que o homem de razão abstrata arruína aquilo que ele deveria conservar e tiraniza aqueles que ele aspira a liberar" ${ }^{\text {"74 }}$. Complementando essa premissa, Rémy Libchaber argumenta que o "conservador é aquele que leva a sério essa racionalidade 'trabalhada por séculos' para obrigar os defensores do progresso, como aqueles do statu quo [os reacionários], a fazer um balanço antecipado da inovação: a situação futura seria melhor que a situação que vivemos hoje ao preço de que riscos previsíveis?"75

Portanto, o "conservadorismo não é de maneira alguma uma nostalgia, uma vez que tem suas bases total-

\footnotetext{
71 Les pensées de Pascal, op. cit., p. 70.

72 Para conhecer as múltiplas expressões do conservadorismo, v. Le dictionnaire du conservatisme, Ch. Boutin, F. Rouvillois, O. Dard (dir.), Paris: Cerf, 2017.

73 R. Libchaber, "L'ouverture de l'assistance médicale à la procréation à toutes les femmes", loc. cit., p. 1882.

${ }^{74}$ R. Aron, Essai sur les libertés, Paris: Pluriel, 1976, p. 75. Apud R. Libchaber, loc. cit., p. 1882.

75 R. Libchaber, "L'ouverture de l'assistance médicale à la procréation à toutes les femmes", loc. cit., p. 1882.
}

mente no presente e que um de seus fortes argumentos é de perpetuar o melhor da tradição para as reformas que podem ser necessárias" ${ }^{76}$. Em outros termos, conclui Libchaber "só devemos afastar-nos da tradição quando os desenvolvimentos defendidos têm méritos individuais e coletivos que podem ser seriamente apreciados e, portanto, superioridade sobre a situação que herdamos. A estabilidade do passado nos ajuda a resistir a um pretenso sentido da história que nos seria imposto sem que pudéssemos a ele resistir" ${ }^{77}$.

Logo, o que propomos com base nessa perspectiva metodológica é o recurso prudente ao direito estrangeiro para fundamentar reformas jurídicas e políticas legislativas e jurisprudenciais. Essa prudência reclama que seja integrada a racionalidade das soluções e das tradições jurídicas na pauta modernizadora. Isso permitiria temperar os anseios e questionar criticamente as premissas progressistas.

Assim, voltando à nossa ilustração inicial, o problema das formas de casamento aceitáveis ou não pela sociedade, suscita, antes de tudo, a questão da função do direito. Longamente concebido como a arte do bom $e$ do justo ${ }^{78}$, o direito parece hoje reduzido a uma mera técnica de enquadramento voluntarista das relações sociais e obrigado a evoluir segundo vontades particulares — quando não egoísticas — de seus protagonistas. Em nossa opinião, a problemática complexa e antiga da definição do direito e sua íntima relação com a proteção do interesse comum deveriam estar no centro das reflexões e dos debates político-jurídicos. Nessa perspectiva, legisladores, juízes e juristas reformistas deveriam se interessar não apenas à eficiência das regras diante dos anseios do tempo, mas também aos seus fundamentos — sobretudo morais —, às suas finalidades e às suas implicações.

Que a comparação jurídica chamada à modernização

76 J.-P., Vicente, Qu'est-ce que le conservatisme? Histoire intellectuelle d'une idée politique, Paris: Les Belles Lettres, 2016, p. 23. Apud R. Libchaber, loc. cit., p. 1882.

77 R. Libchaber, "L'ouverture de l'assistance médicale à la procréation à toutes les femmes" loc. cit., p. 1882.

78 Dig. 1.1.1.pr. - Ulpiano: "quem deseja aplicar-se ao estudo do direito deve, primeiro que tudo, conhecer de onde deriva essa denominação. É assim chamado de "justiça"; pois como muito bem define Celso, o direito é a arte do bom e do justo". Digesto ou Pandectas do Impedador Justriniano, tradução brasileira por Manoel da Cunha Lopes e vasconcelos, revista e completada por E. Marchi, B. Queiroz der Moraes e D. Martins Rodrigues, vol. I, São Paulo: YK Editora, 2017, p. 62. 
do direito siga, pois, a boa razão. Aquela conforme ao bem comum de uma Nação, definido de maneira civilizada, dentro de um amplo diálogo respeitoso e construtivo entre não apenas os que aspiram a mudanças, mas entre estes e aqueles que, sem se oporem peremptoriamente à evolução do direito, agem com prudência em vistas aos seus fundamentos e às suas consequências.

\section{Referências}

I. Aguilar Vieira, "A atualidade do direito comparado ou o direito comparado no fio do tempo", in I. Aguilar Vieira (org.), Estudos de direito comparado e de direito internacional privado (tomos I e II), prefácio A. Wald, Curitiba: Juruá, 2011, p. 279-320.

e G. Cerqueira, "L'influence du Code de commerce français au Brésil (Quelques remarques sur la commémoration du bicentenaire du Code français de 1807)", Revue internationale de droit comparé, 1-2007, p. 2777.

M. Ancel, "Politique législative et Droit comparé", Mélanges Maury, t. II, Paris: Dalloz-Sirey, 1960, p. 9-23.

Aristote, Éthique à Nicomaque, Paris: Flamarion, 2007.

R. Aron, Essai sur les libertés, Paris: Pluriel, 1976.

J. du Bois Gaudusson e F. Ferrand (dir.), La concurrence des systèmes juridiques, Aix-en-Provence: PUAM, 2008.

Ch. Boutin , F. Rouvillois, O. Dard (dir.), Le dictionnaire du conservatisme, Paris: Cerf, 2017.

J. Carbonnier, Essais sur les lois, Paris: Defrénois, 1979.

G. Cerqueira, "La justiciabilité du droit souple au regard de la réforme de la Cour de cassation", in T. Hochmann et alii (dir.), Le contrôle juridictionnel du droit souple, Reims: EPURE, 2017, p. 137-173.

"Libre circulation des sociétés en Europe: concurrence ou convergence des modèles juridiques", Revue trimestrielle de droit européen, 1-2014, p. 7-38.

. "Les données fondamentales pour la comparaison juridique en droit privé", in G. Cerqueira et alii. (dir.), Les frontières entre liberté et interventionnisme en droit français et en droit brésilien, Paris: L'Harmattan, 2010, p. 67-149.

e C. Lima marques, A função modernizadora do direito comparado - 250 anos da Lei da Boa Razãa, São Paulo: YK Editora, 2020 (no Prelo). e G. Choisel, "La reserve héréditaire en droit français: vers la renonciation à un héritage romain?”, Вестник Омского университета. Серия: Право [Mensageiro da Universidade de Omsk. Série: Direito], vol. 17, 2020, n. ${ }^{\circ}$ 1 (no prelo).

G. Choisel, "D'un changement de définition à un droit en attente de reconstruction. Réflexions sur l'étendue des conséquences juridiques de la loi ouvrant le mariage aux couples de personnes de même sexe", Revue trimestrielle de droit civil, 3-2015, p. 505-516 (reproduzido em língua portuguesa na Revista de Direito Civil Contemporâneo, vol. 11 (2017), p. 299 et seq., tradução de I. de Aguilar Vieira).

G. Cornu (dir.), Vocabulaire juridique, $13^{\mathrm{a}}$ ed., Paris: Puf, 2020.

J. H. Correia Telles, Commentario crítico á Lei da Boa Razão, em data de 18 de agosto de 1769, Lisboa: Typografia de N. P. de Lacerda, 1824.

Cour de cassation, Rapport annuel 2018.

Ph. Delebecque, “'L'attractivité' du droit français : un mot d'ordre dépourvu de sens?", in Mélanges en l'honneur du professeur Laurent Aynès, Paris: LGDJ, 2019, p. 185 et seq.

R. Demogue, Notions fondamentales du droit privé. Essai critique pour servir d'intriduction an droit, LGDJ, 1911.

O. Deshayes et alii, Réforme du droit des contrats, du régime general et de la preuve des obligations. Commentaire article par article, $2^{\mathrm{e}}$ éd., LexisNexis, 2018.

"La mort des attendus", Revue des contrats, 4-2018, p. 531.

Digesto ou Pandectas do Impedador Justriniano, tradução brasileira por Manoel da Cunha Lopes e vasconcelos, revista e completada por E. Marchi, B. Queiroz der Moraes e D. Martins Rodrigues, vol. I, São Paulo: YK Editora, 2017.

M. Fabre-Magnan, La gestation pour autrui. Fictions et réalité, Fayard, 2013.

B. Fauvarque-Cosson, "Deux Siècles d'évolution du droit comparé", Revue internationale de droit comparé, 3-2011, p. 527-540.

L'impossibilité d'une gestation pour autrui 'éthique' ", in Archives de Philosophie du Droit - La famille en mutation, t. 57, 2014, p. 465-484. 
M. A. Frison-Roche, "Une famille à sa main", Archives de Philosopbie du Droit - La famille en mutation, t. 57, 2014, p. 249-265.

P. Gelard, "Quelques conseils au constitutionnaliste de droit comparé", Mélanges en l'honneur de L. Favoreu, Renouveau du droit constitutionnel, Paris: Dalloz, 2007, p. 705-711.

J.-P. Gridel, "La motivation aux défis de la modernité - Entre le Charybde de l'hermetisme et le Scylla du bavardage", JCP G, n. ${ }^{\circ}$ 5, 2020, p. 242-249.

B. Haftel, "Libres propos sur l'avant-projet de réforme de la Cour de cassation et la fonction du juge", Recueil Dalloz 2015, p.1378.

S. Harnay et J.-S. Bergé, "Concurrence entre règles juridiques et construction européenne : à propos de l'analyse économique du droit", Etudes en l'honneur du professeur Michel Bazex, Litec, 2009, p. 15-25.

"Les analyses économiques de la concurrence juridique : un outil pour la modélisation du droit européen", Revue internationale de droit économique, 2-2011, t. XXV, p. 165-192.

P. Jestaz, J.-P. Marguénaud, C. Jamin, "Révolution tranquille à la Cour de cassation”, Recueil Dalloz, 2014, p. 2061.

Ch. Larroumet, "Le mythe de l'attractivité du droit civil français", in Liberté, justesse, autorité. Mélanges en l'bonneur du professeur Laurent Aynès, Paris: LGDJ, 2019.

Y. Lequette, Les mutations du droit international privé : vers un changement de paradigme? Cours général de droit international privé, RCADI, t. 387 (2017).

"L'ouverture du mariage aux personnes de même sexe : clarification et réflexions", in D. Mazeaud et Y. Lequette (dir.), L'ouverture du mariage aux personnes de même sexe, Éd. Panthéon-Assas, 2014, p. 13 et seq.

Le mode de rédaction des arrêts de la Cour de cassation change - Dossier de presse. Disponível em : https://www.courdecassation.fr/IMG///mode_de_redaction_01.07.19_ v2.pdf

Les pensées de Pascal, reproduites d'après le texte autographe, disposées selon le plan primitif et suivies des Opuscules / édition philosophique et critique, enrichie de notes et précédée d'un Essai sur l'apologétique de Pascal, par A. Guthlin, Paris: P. Lethielleux, 1896.

R. Libchaber, "L'ouverture de l'assistance médicale à la procréation à toutes les femmes", Recueil Dalloz 2018, n. ${ }^{\circ} 34$, p. $1875-1883$.
"Des successions en quête d'avenir", Revue trimestrielle de droit civil, 2016, p. 729-750.

B. Louvel, "Pour exercer pleinement son office de Cour suprême, la Cour de cassation doit adapter ses modes de controle", JCP G, 2015, p. 1122.

F. Malhière, La brièveté des décisions de justice (Conseil constitutionnel, Conseil d'État, Cour de cassation) - Contribution à l'etude des représentations de la justice, préf. D. Rousseau, Paris: Dalloz, 2013.

Montesquieu (Charles Louis de Secondat, baron de La Brède et de Montesquieu), De l'esprit des lois, t. 1, présentation par V. Goldschmidt, Paris: GF Flamarion, 1979.

H. Muir Watt, "Concurrence d'ordres juridiques et conflit de lois de droit privé", Mélanges P. Lagarde, Dalloz, 2005, p. 615-633.

S. Piédelièvre, "Du passé, ne faisons pas table rase", Recueil Dalloz 2019, p. 1547-1548.

J. Pradel, "Les pièges du droit comparé", Écrits en hommage de Gérard Cornu, Paris: Puf, 1994, p. 345-357.

Projet de loi ouvrant le mariage aux couples de personnes de même sexe - Étude d'impact, novembre 2012, disponível em: http://www.assemblee-nationale.fr/14/projets/pl0344ei.asp\#P445_49423 (consultado em 7 de julho de 2019).

Regards d'universitaires sur la réforme de la Cour de cassation, JCP G - suppl. au n. ${ }^{\circ}$ 1-2, janv. 2016.

Rapport au Président de la République relatif à l'ordonnance $n .^{\circ}$ 2016-131 du 10 février 2016 portant réforme du droit des contrats, du régime général et de la preuve des obligations (JORF n. ${ }^{\circ} 0035,11$ février 2016, texte . $\left.^{\circ} 25\right)$.

Rapport de la Commission de réflexion sur la réforme de la Cour de cassation, avril 2017, disponível em: https:// www.courdecassation.fr/cour_cassation_1/reforme_ cour_7109/

R. Saleilles, "Conception et objet de la science du droit comparé", in Congrès international de droit comparé tenu à Paris du 31 juillet an 4 août 1900: procès-verbaux des séances, Paris: LGDJ, 1905, p. 167-189, p. 168.

R. Sefton-Green et L. Usunier (dir.), La concurrence normative, Mythes et réalités, Paris: Société de législation comparée, 2013.

J.-L. Sourioux, "Notule sur le droit comparé dans les travaux préparatoires du Code civil des Français", in De tous horizons. Mélanges Xavier Blanc-Jouvan, Paris: Société 
de législation comparée, 2005, p. 159-163.

J. Théron, "Sublimer l'essence de la Cour de cassation ? À propos du rapport de la Commission de réflexion sur la réforme de la Cour de cassation - Aperçu rapide", JCP G, n. ${ }^{\circ} 24,12$ juin 2017, p. 1139-1142.

A. Touffait e A. Tunc, "Pour une motivation plus explicite des décisions de justice, notamment de celles de la Cour de cassation", Revue trimestrielle de droit civil, 1974.

L. Usunier, "A contribuição do direito comparado à reforma do direito francês das obrigações", in G. Cerqueira e C. Lima Marques (dir.), A função modernizadora do direito comparado - 250 anos da Lei de Boa Razãa, São Paulo: YK Editora, 2020 (no prelo).

"L'attractivité internationale du droit français au lendemain de la réforme du droit des contrats, ou le législateur français à la poursuite d'une chimère", Revue trimestrielle de droit civil, 2-2017, p. 343-349.

J.-P. Vicente, Qu'est-ce que le conservatisme? Histoire intellectuelle d'une idée politique, Paris: Les Belles Lettres, 2016.

F. Zenati-Castaing, "La juridictionnalisation de la Cour de cassation", Revue trimestrielle de droit civil, 3-2016, p. 511 et seq.

\section{Decisões}

Corte de Cassação francesa, $1^{\text {a }}$ Câmara civil (Cass. $1^{\text {re }}$ Civ.), 13 de março de 2007, n. ${ }^{\circ}$ 05-16.627.

Corte de Cassação francesa, $1^{\text {a }}$ Câmara civil (Cass. $1^{\text {re }}$ Civ.), 27 de setembro de 2017, n. ${ }^{\circ} 16-17.198$ e n. ${ }^{\circ} 16-$ 13.151

Corte Europeia de Direito Humanos (CEDH), 24 de junho de 2010, Schalk et Kopf c/ Autriche, n. ${ }^{\circ}$ 30141/04.

Conselho Constitucional francês (Cons. const.), 28 de janeiro de 2011, Decisão 2010-92 QPC. 
Para publicar na Revista de Direito Internacional, acesse o endereço eletrônico www.rdi.uniceub.br ou www.brazilianjournal.org.

Observe as normas de publicação, para facilitar e agilizar o trabalho de edição. 